\title{
ДОХОДИ, ЩО МОЖУТЬ СТАТИ ПРЕДМЕТОМ ПРЕДИКАТНОГО КРИМІНАЛЬНОГО ПРАВПОРУШЕННЯ
}

\author{
ГОНЧАРУК Владислав Леонідович - Національна академія Служби \\ безпеки України, старший науковий співробітник наукової лабораторії науково- \\ організаційного центру
}

УДК 343.2/.7

DOI 10.32782/NP.2020.4.13

\begin{abstract}
Недоліки кримінального законодавства щодо притягнення до відповідальності за вчинення суспільно небезпечних діянь, пов'язаних з легалізацією (відмиванням) майна, одержаного злочинним шляххм, у достатній мірі ускладнюють можливості кримінально-правової протидї таким негативним суспільним явищам. Необхідність забезпечення правильної квалібікачї̈ злочинних дій, у результаті вчинення яких набувається майно, потребує формування концептуального підходу до закріплених у ст. 209 КК України категорій, якими узагальнюються сучасні предмети матеріального світу, одержані в такий незаконний спосіб.
\end{abstract}

Ключові слова: предикатний злочин, легалізачія (відмивання) майна, доходи, майно, активи.

Метою статті $є$ вироблення наукового обгрунтування до визначення складових категорій «доходи, одержані злочинним шляхом» та надання конкретних пропозииій для вдосконалення законодавства в изй сфері.

Наукова новизна дослідження пов'язана iз подальшим розвитком наукової думки щодо дебініиій «майно», «доходи», а також «активи, одержані злочинним иляхом». З'ясовано значення та співвідношення категорій «кошти» та «валютні изінності».

На підставі критичного аналізу норм вітиизняного кримінального законодавства, а також Закону України від 06.12.2019 № 361IX «Про запобігання та протидію легалізаиї (відмиванню) доходів, одержаних злочинним шляхом, бінансуванню тероризму та фінансуванню розповсюдження зброї масового знищення», набули розвитку нормативно-правові положення шодо предметів матеріального світу, які відносяться до категорї майно та доходи, одержані внаслідок вчинення кримінального правопорушення. На підставі теоретичного узагальнення сформовано авторсъке бачення до вдосконалення норм законодавства в иій сфері.

Висновки. Підсумовуючи, зазначимо, що iз набуттям чинності Закону України від 06.12.2019 № 361-IX «Про запобігання та протидію легалізациї (відмиванню) доходів, одержаних злочинним шляхом, бінансуванню тероризму та бонансуванню розповсюдження зброї масового знищення», а також нової редакиї ст. 209 КК України, набули змін підходи до борммлюювання ббізичної ознаки предмету предикатних злочинних дій. Однак закріплені в нормах зазначених законодавчих актів категоріі манть невідповідності та потребують узгодження.

Категорія доходи, одержані злочинним шляхом, є родовою категорією та поєднує у собі предмети матеріального світу, які матоть вартісну оцінку та набуті внаслідок вчинення суспільнонебезпечного діяння, за яке передбачена кримінальна відповідальність.

Авторсъкий підхід до вдосконалення норм Закону Украӥни від 06.12.2019 № 361-IX, а також ч. $1 \mathrm{~cm} .209$ КК Украӥни передбачає, що з точки зору кримінального права, деталізачія в зазначеній нормі кримінального законодавства видів або груп майна має відносний характер та для квалібікаиї значення не має, однак з метою уникнення розбіжностей при тлумаченні норм вітчизняного кримінального закону, а також базового закону з питань запобігання та протидію легалізацї (відмиванню) доходів, одержаних злочинним шляхом, має бути забезпечений однаковий підхід до визначень основних категорій, якими охоплюються предмети матеріального світу, які можуть стати предметом предикатного кримінального правопорушення. 


\section{Кримінальне право, кримінальний процес та криміналістика}

\section{Постановка проблеми}

Законодавство про кримінальну відповідальність формує дієвий механізм охорони прав і свобод людини і громадянина, власності, громадського порядку та громадської безпеки, довкілля, конституційного устрою України від кримінально-протиправних посягань, забезпечення миру і безпеки людства, а також запобігання кримінальним правопорушенням. Для реалізації такої мети законодавчими положеннями визначаються, які суспільно небезпечні діяння $є$ кримінальними правопорушеннями та які покарання застосовуються до осіб, що їх вчинили. Саме тому ефективність функціонування такого механізму, а також ступінь реалізації мети кримінального законодавства залежать від правильності закріплених ознак тих чи інших складів кримінальних правопорушень, відповідно до яких буде здійснюватися кваліфікація дій.

У зв'язку із систематичним виконанням Україною Рекомендації FATF та 4-ї і 5-ї Директиви Свропейського Союзу проти відмивання коштів та фінансування тероризму, які вже впроваджені в усіх країнахчленах EC та є обов’язковою для країн, що мають намір на членство, достатньо важливим питанням $є$ усунення недоліків та вдосконалення вітчизняного кримінального законодавства щодо кримінально-правової протидії легалізації (відмиванню) майна, одержаного злочинним шляхом, у т.ч. й предикатним злочинним діянням.

Саме у зв'язку із набранням чинності Закону України «Про запобігання та протидію легалізації (відмиванню) доходів, одержаних злочинним шляхом, фінансуванню тероризму та фінансуванню розповсюдження зброї масового знищення» (далі - Закон від 06.12.2019 № 361-IX) редакція статті 209 КК України зазнала змін та була викладена в іншій редакцій, зокрема щодо предмета кримінального правопорушення, що й вплинуло на можливості кваліфікацій дій, пов'язаних із злочинним способом одержання певних активів та дій, направлених на імітацію законності джерел їх походження.
Аналіз останніх наукових публікацій

Проблеми кримінальної-правової протидії легалізації (відмиванню) майна, одержаного злочинним шляхом, традиційно привертають увагу науковців, оскільки зазначена тематика $\varepsilon$ важливою як на національному, так і міжнародному рівнях. Також такий інтерес зумовлений необхідністю адаптації національного законодавства до світових стандартів у цій сфері, а також наявністю прогалин у чинному Кримінальному кодексі України та неузгодженістю окремих норм законодавства в цій сфері.

Загальні положення проблематики кримінально-правової характеристики таких діянь висвітлювалась у наукових працях таких учених, як: Ашина Д.А., Бадзана M.I., Бажанова М.I., Бауліна Ю.В., Борисова В.I., Будзана M.I., Галочки Г.В., Киричко В.M., Кухаря В.В., Мельника М.I., Сташиса В.В., Тація В.Я., Чаричанського О.О., Тулякова B.О., Тютюгіна В.I., Ховранюка М.I. та багатьох інших. Науковий доробок учених створює належне підгрунтя для подальших наукових досліджень, однак, у зв'язку із набранням чинності у 2019 році законодавства щодо запобігання та протидії легалізації (відмиванню) доходів, одержаних злочинним шляхом, фінансуванню тероризму та фінансуванню розповсюдження зброї масового знищення, окремі положення, зокрема щодо фізичних ознак предмета кримінального правопорушення, від чинення яких було одержано дохід, потребують переосмислення.

Метою статті є дослідження складових категорії «доходи, одержані злочинним шляхом» та надання конкретних пропозицій для вдосконалення законодавства в цій сфері.

\section{Виклад основного матеріалу}

Питання економічної вигоди від вчиненого кримінального правопорушення лежить у площині проблематики предмета суспільно небезпечного діяння, за яке передбачена кримінальна відповідальність, y т.ч. його значення та місця в структурі складу злочину. 
У теорії кримінального права значення цієї категорії прийнято розглядати як будъякі речі матеріального світу, із певними властивостями яких кримінальний закон пов'язує наявність у діях особи ознак конкретного складу злочину [1].

Саме пряме посилання вітчизняного закону про кримінальну відповідальність на певні ознаки чи властивості певної речі призводить до того, що предмет, який, як правило, не є самостійною ознакою загального поняття складу злочину, набуває обов'язкового характеру для кваліфікації кримінального правопорушення. Те ж саме стосується і тих випадків, коли предмет злочину однозначно випливає зі змісту кримінального правопорушення. На нашу думку, фахівці у галузі кримінального права цілком правильно виокремлюють такі склади кримінальних правопорушень в окрему групу, які ще називають як предмети [2, с. 52].

Вважаємо, що такий підхід дозволяє правильно кваліфікувати фактичні обставин вчиненого кримінального правопорушення, та, як слушно зазначив Тацій В.Я., саме через предмет можливо визначити об'єкт, з'ясувати його зміст, характер посягання, а також спосіб впливу на нього [3, c. 56].

Чаричанський О.О. у своєму дисертаційному дослідженні, аналізуючи підстави кримінальної відповідальності за легалізацію (відмивання) доходів, одержаних злочинним шляхом, дійшов цілком справедливого висновку про те, що злочин, передбачений ст. 209 КК України, є предметним [2, с. 53].

Якщо ж порівнювати положення статті 209 КК України в редакції від 2003 року, саме на підставі аналізу диспозиції якої Чаричанський О.О. й висловив вищевказану сентенцію, з чинною редакцією норми, зазначене ним вище не втрачає своєї ваги.

Ретроспективний аналіз розвитку положень значеної статті Кримінального кодексу України дає підстави говорити, що вони були похідними саме від змін вітчизняного законодавства, орієнтованого на реалізацію взятих Україною на себе міжнародних зобов’язань щодо впровадження світових стандартів у сфері боротьби з відмиванням «брудних» доходів та фінансування тероризму. Саме так норма статті 209 КК України набула чинності у зв'язку з прийняттям Закону України «Про запобігання та протидію легалізації (відмиванню) доходів, одержаних злочинним шляхом, фінансуванню тероризму та фінансуванню розповсюдження зброї масового знищення» від 06.12.2019 № 361-IX [4].

Відчутним результатом цього стало впровадження нових стандартів FATF, які у порівнянні 3 попередніми Рекомендаціями [5] посилили вимоги до національних систем протидії відмиванню коштів та фінансуванню тероризму та, відповідно, уточнили зміст категорії «предикатний злочин», знявши будь-які обмеження в підходах до кваліфікації злочинних діянь, внаслідок вчинення яких виникли доходи, що можуть стати предметом кримінального правопорушення, передбаченого статтею 209 КК України.

Чинна редакція диспозиції даної статті так само містить пряму вказівку на конкретний предмет злочину, а відтак, вважаємо, що розвиток вітчизняного кримінального законодавства направлений на вдосконалення змісту закріпленої, в нормах права конструкції предикатного злочину, згідно 3 якою кримінальний закон пов'язує наявність у діях особи ознак складу кримінального правопорушення із певними властивостями речей матеріального світу.

Слід зазначити, що як у назві, так і в диспозиції ст. 209 КК України законодавець достатньо чітко сформулював положення про предмет злочину, вказавши на «майно, одержане злочинним шляхом». Інакше кажучи, зазначеним вище закріплена редакція норми сформулювала легальне визначення фізичних (майно) та юридичних ознак (злоиинний шлях його одержання) предмета легалізації, які також є визначальними для розуміння конструкції предикатного злочину, саме яка і є зовнішнім проявом останньої $з$ ознак.

Можемо констатувати, що вітчизняний закон про кримінальну відповідальність закріплював не однакові підходи до формулювання саме фізичної ознаки предмета 


\section{Кримінальне право, кримінальний процес та криміналістика}

кримінального правопорушення, передбаченого статтею 209 КК України. Так, у першій редакції норми предмет легалізації був визначений як «грошові кошти та інше майно, здобуті злочинним шляхом», у подальшому - «доходи, одержані злочинним шляхом» [6], пізніше у 2019 році як легальне його визначення була закріплена категорія «майно, одержане злочинним шляхом» [7]. Неоднозначність у підходах до визначення цієї фізичної ознаки предмета легалізації вплинули на розвиток наукової думки щодо речей матеріального світу, отриманих злочинним шляхом, як обов'язкової складової ознак для правильної кваліфікації дій за статтею 209 КК України.

Характеризуючи названу ознаку слід зазначити, що у парадигмі кримінального права під предметом злочину розуміють «будь-які речі матеріального світу, із певними властивостями яких кримінальний закон пов'язує наявність у діях особи конкретного злочину» [8]. У чинних положеннях вітчизняного Кримінального кодексу про предмет легалізації термін «майно»не розкривається, а конкретизується лише посиланням на спосіб одержання означеного майна злочинним шляхом, а також його частку. Разом з тим, чинний Закон України «Про запобігання та протидію легалізації (відмиванню) доходів, одержаних злочинним шляхом, фінансуванню тероризму та фінансуванню розповсюдження зброї масового знищення» [7] у визначеннях термінів використовує термін не «майно», а йдеться вже про «доходи» та розкиває його значення як будв-які активи, одержані прямо ии опосередковано внаслідок вчинення злочину, зокрема валютні иінності, рухоме та нерухоме майно, майнові та немайнові права, незалежно від їх вартості.

До набрання чинності вищевказаного положення як у Кримінальному кодексі України, так і в Законі України «Про запобігання та протидію легалізації (відмиванню) доходів, одержаних злочинним шляхом, фінансуванню тероризму та фінансуванню розповсюдження зброї масового знищення» [9] був закріплений інший підхід, згідно з яким категорія "доходи, одержані злочинним шляхом» визначались як будъ- яка економічна вигода, одержана внаслідок виинення суспільно небезпечного діяння, що передує легалізації (відмиванню) доходів, яка може складатися $з$ матеріальної власності ии власності, що виражена в правах, а також включати рухоме чи нерухоме майно та документи, які підтверджують право на таку власність або частку в ній.

На підставі порівняльного аналізу вищевказаних законодавчих підходів до визначення поняття «доходів, одержаних злочинних шляхом», вважаємо, що за фізичними ознаками предмета кримінального правопорушення вони співпадають, однак за юридичними ознаками чинна редакція норми 6 більш вдалою, оскільки нею враховано положення саме про злочинний характер походження таких активів, а не вчинення будьякого іншого протиправного діяння, наприклад адміністративного правопорушення.

Слід зазначити, що нормативне визначення категорії “доходи» не місить прямого посилання на термін «кошти», який, по суті, є достатньо поширеним прикладом економічної вигоди від вчиненого певного кримінального правопорушення. Саме тому такий підхід вже мав місце у першій редакції норми, де предмет легалізації так i визначався як «грошові кошти та інше майно, здобуті злочинним шляхом», про що вже зазначалося вище. Проте, тоді як у теорії, так і на практиці поняття «гроші» розглядалося як родове поняття, тобто як таке, що вбирало в себе й інші види економічної вигоди. Подібного висновку дійшов Чаричанський О.О., зазначивши, що термін «кошти», використаний законодавцем при характеристиці предмета злочину, є узагальненим і включає не тільки грошові кошти, а й інше майно [2, с. 54]. Підтримуємо зазначену позицію науковця.

Разом 3 тим, системний аналіз визначень основних термінів у Законі України від 06.12.2019 № 361-IX дає можливість виділити кілька понять, які дозволяють окреслити законодавчий підхід до визначення змісту дефініції «доходи», а також сформувати уяву про категорії речей матеріального світу, саме із певними властивостями яких кримінальний закон і пов'язує наявність у діях особи конкретного злочину. 
Оскільки значення терміна «доходи» розкривається саме через поняття «активи», слід звернути увагу на те, що його зміст визначається через «кошти, у тому иислі електронні гроші, інше майно, майнові та немайнові права». Вважаємо, що запропонована редакція норми дозволила закріпити саме узагальнений підхід до тлумачення цієї категорії.

Варто зазначити, що як у Кримінальному кодексу України, так і Законі України від 06.12.2019 № 361-IX як прямої, так і відсилочної норми-тлумачення категорії «кошти» не міститься. Згадана категорія безпосередньо закріплена у Законі України «Про банки та банківську діяльність» [10], зокрема у ст. 2 зазначено, що кошти - це гроші у національній або іноземній валюті чи $\ddot{x}$ еквівалент.

Іншими нормативно-правовими актами у сфері регулювання кредитно-фінансової системи, наприклад, Законом України «Про платіжні системи та переказ коштів в Україні» [11] у ст. 3 вказується, що кошти існують у готівковій бормі (бормі грошових знаків) або безготівковій бормі (бормі записів на рахунках банків), відповідно до п. 1.4. Інструкції про безготівкові розрахунки в Україні в національній валюті, затвердженої постановою Національного банку України від 21.01.2004 № 22 [12], це грошова одиниия України, яка виконує функиію засобів платежу та обліковується на рахунках у банках, а згідно із п. 3 Національного стандарту бухгалтерського обліку, це готівка, кошти на рахунках у банках та депозити до запитання [13]. Щодо останнього слід зазначити: вчений-економіст Губарик О.М., досліджуючи сучасні вітчизняні підходи до визначення поняття «грошові кошти та їх еквіваленти» в національному та міжнародному обліку, дійшов висновку, що в цілому вони відповідають міжнародним стандартам бухгалтерського обліку [14].

Етимологічно грошові кошти (англ. monetary assets) розкриваються як доходu $i$ надходження, шо акумулюються в грошовій бормі на рахунках підприємств, організацій, установ $i$ домашніх господарств у банках $i$ використовуються для забезпечення їхніх власних потреб або розмішення у вигляді ресурсів банків
[15, с. 60]. У довідникових джерелах визначені як готівкова валюта України $i$ готівкова іноземна валюта у вигляді банкнот і монет, щзо перебувають в обігу та є законним платіжним засобом на території відповідної держави, банкноти та монети, вилучені з обігу або такі, що вилучаються з нього, але підлягають обмінові на грошові знаки, які перебувають в обігу (крім монет, що належать до банківських металів), $i$ дорожні чеки [16, с. 48].

На підставі аналізу зазначених вище положень, вважаємо, що норми чинного законодавства такі поняття, як «кошти», «гроші» або «грошові кошти», не передбачають використання їх як узагальнених або ж, як ще можна сказати, родових категорій при аналізі фізичних властивостей предмета легалізації. Інакше кажучи, зазначені дефініції слід тлумачити як видові поняття, тобто окремі сукупності предметів, що мають власні специфічні властивості.

Системний аналіз вищевказаних визначень та понять інших дає можливість вказати на недоліки юридичної техніки в Законі України від 06.12.2019 № 361-IX, зокрема в частині визначення змісту поняття «активи». Законодавець у межах однієї і тієї ж норми закону (ст. 1), вказавши, що активи - це кошти, у тому иислі електронні гроші, інше майно, майнові та немайнові права (п. 2), розкриваючи далі по тексту значення категорії «доходи, одержані злочинним шляхом» (п. 23) поклав в основу його визначення вже згадану дефініцію «активи», однак застосував інші словосполучення для розкриття його змісту, а саме: валютні иінності, рухоме та нерухоме майно, майнові та немайнові права, незалежно від їх вартості.

Вирішуючи це питання, слід сказати, що згадка про таку категорію як «валютні цінності» міститься в Цивільному кодексі України, однак у статті 193 міститься лише відсилочна норма до іншого законодавства для визначення видів майна, що вважаються валютними цінностями, та порядку вчинення правочинів 3 ними [17]. Нормами спеціального законодавства 3 цього приводу є положення Закону України «Про валюту і валютні операції» [18], де власне і закріплено поняття «валютні иінності» (ст. 1), під якими слід розуміти національну валю- 


\section{Кримінальне право, кримінальний процес та криміналістика}

ту (гривню), іноземну валюту та банківсъкі метали. Базуючись на положеннях цього закону, можна констатувати, що поняттям валютні цінності як у цивільному, так і кримінальному вітчизняному законодавстві фактично охоплені:

а) іноземна валюта, яка включає, по-перше, грошові знаки грошових одиниць іноземних держав у вигляді банкнот, казначейських білетів, монет, що перебувають в обігу та $є$ законним платіжним засобом на території відповідної іноземної держави або групи іноземних держав, а також вилучені або такі, що вилучаються з обігу, але підлягають обміну на грошові знаки, що перебувають в обігу; по-друге, кошти на рахунках у банках та інших фінансових установах, виражені у грошових одиницях іноземних держав i міжнародних розрахункових (клірингових) одиницях (зокрема у спеціальних правах запозичення), що належать до виплати в іноземній валюті; nо-третє, електронні гроші, номіновані у грошових одиницях іноземних держав та (або) банківських металах;

б) національна валюта (гривня), яка, у свою чергу, також включає, по-перше, грошові знаки грошової одиниці України гривні у вигляді банкнот, монет, у тому числі обігових, пам'ятних та ювілейних монет, і в інших формах, що перебувають в обігу та є законним платіжним засобом на території України, а також вилучені або такі, що вилучаються з обігу, але підлягають обміну на грошові знаки, що перебувають в обігу; по-друге, кошти на рахунках у банках та інших фінансових установах, виражені у гривні; no-mpeme, електронні гроші, номіновані у гривні (ст. 1) [18]. Підтримуємо такий підхід законодавця, зважаючи на те, що він спирається на сучасний науковий доробок у цій сфері [2, с. 55-56].

Зважаючи на викладене, вважаємо що поняття «гроші (грошові кошти)» $е$ вужчим та поглинається категорією «валютні цінності», інакше кажучи $є$ його складовою.

Що стосується визначення змісту дефініції «майно», то це одне $з$ фундаментальних понять вітчизняної цивілістики, котре відіграє достатньо важливу роль у категоріальному апараті інших галузей права [19], у т.ч. і кримінального права. За цивільним законодавством це поняття охоплює окрему річ, сукупність речей, а також майнові права й обов'язки (ст. 190 ЦКУ) [17]. У цілому, як у теорії цивільного законодавства, так і інших галузей законодавства існують різні підходи до визначення цієї категорії. Щодо цього Гузь E.В. дійшов такого ж висновку та вважає, що юридичний зміст поняття «майно» чітко не визначений та припускає багатоваріантність тлумачення, а проведений аналіз сучасного наукового доробку 3 цього питання дозволив йому сформулювати узагальнений підхід до його визначення, згідно $з$ яким «майно» означає будь-які активи, матеріальні або нематеріальні, рухомі або нерухомі, виражені в речах або в правах, які є предметом иивільного обороту і правового захисту [19, с. 184-185]. Вважаємо, що такий підхід прийнятний та як такий, що чинному законодавству не суперечить.

У кримінальному судочинстві термін на підставі узагальненої практики застосування судами законодавства про відповідальність за злочини проти власності «майно» розглядається як категорія, що має певну вартість та охоплюе речі (рухомі й нерухомі), грошові кошти, иінні метали, иінні папери тощо, а також право на майно та дї майнового характеру, електрична та теплова енергія [20].

Розглядаючи це питання тільки в межах предмета нашого дослідження, зазначимо, що аналіз наведених вище положень дає нам підстави розглядати категорію «майно» у розширеному значені, тобто як родове поняття, котре, у свою чергу, охоплює всі предмети матеріального світу, що мають певну вартість або можуть бути піддані вартісній оцінці. 3 точки зору кримінального права, деталізація видів або груп майна має відносний характер, оскільки чинна норма ст. 209 КК України вживає цей термін у розширеному значенні. Такий підхід вважаємо вдалим, оскільки він дозволяє враховувати можливі зміни форми матеріального вираження майна, яке може стати предметом будь-якого кримінального правопорушення.

Відповідно, в умовах незавершеного характеру формулювання усталеного підходу саме до юридичного змісту поняття «майно», а також достатньо швидкого розвитку 
цивільних та господарських правовідносин, надмірна деталізація його різновидів у ст. 209 КК України, на нашу думку, негативно вплине на можливості кримінально-правової протидії такому злочинному діянню, як легалізації (відмиванню) доходів, одержаних злочинним шляхом, адже невраховані кримінальною нормою різновиди такого майна не дозволять правильно кваліфікувати відповідні суспільнонебезпечні дії за цією нормою.

Характеризуючи співвідношення категорій майно та доходи, одержані злочинним шляхом, вважаємо, що вони є взаємодоповнюючими та в сукупності складають зміст особливостей фізичної ознаки предмета предикатних злочинних дій. Разом 3 тим, за результатами порівняльно-правового аналізу положень Закону України від 06.12.2019 № 361-IX та чинної редакції ст. 209 КК України, зазначені дефініції саме у розумінні використаного законодавчого підходу для узагальнення сучасних предметів матеріального світу, отриманих злочинним шляхом, на нашу думку, вжиті у синонімічному значенні.

3 метою уникнення розбіжностей при тлумаченні норм вітчизняного кримінального закону, а також базового закону з питань запобігання та протидію легалізації (відмиванню) доходів, одержаних злочинним шляхом [8], вбачаємо за доцільне, поперше, уніфікувати законодавчі підходи до використання основних категорій та викласти норму частини 1 статті 209 КК України у наступній редакції: «Cmammя 209. Аeгалізачія (відмивання) доходів, одержаних злочинним иляхом. 1. Набуття, володіння, використання, розпорядження доходами, щодо якого ббактичні обставини свідчать про ї одержання злочинним шляхом, у тому иислі здійснення фбінансової операџї, вчинення правочину з такими активами, або переміщення, зміна борми (перетворення) таких активів, або вчинення дій, спрямованих на приховування, маскування походження таких активів або володіння ними, права на такі активи, джерела їх походження, місиезнаходження, якщо иі діяння вчинені особою, яка знала або повинна була знати, що такі доходи прямо чи опосередковано, повністю чи частково одержа- но злочинним шляхом,»; по-друге, доповнити положення ч. 2 ст. 1 Закону України від 06.12.2019 № 361-IX відсилочною нормою наступного змісту «термін «майно»вживається у значенні, неведеному у Цивільному кодексі Украӥни»; по-третє, У п. 2 ч. 1 ст. 1 названого Закону конкретизувати термін «активи», виклавши норму у наступній редакції «активи - валютні цінності, інше майно, майнові та немайнові права»; по-четверте, у п. 23 ч. 1 ст. 1 цього ж Закону у визначенні терміну «доходи» слово «зокрема», замінити на «у тому числі» та викласти норму у наступній редакції «доходи, одержані злочинним шляхом - будь-які активи, одержані прямо чи опосередковано внаслідок вчинення злочину, у тому иислі валютні иінності, рухоме та нерухоме майно, майнові та немайнові права, незалежно від їх вартості».

\section{Висновки}

Підсумовуючи, зазначимо, що впровадження сучасних світових підходів щодо регулювання суспільних відносин 3 притягнення до кримінальної відповідальності за легалізацію (відмивання) майна, одержаного злочинним шляхом, у зв'язку із внесенням відповідних змін до вітчизняного законодавства в цій сфері, вплинули на зміну визначення кримінального правопорушення, передбаченого ст. 209 КК України, у т.ч. давні підходи до формулювання фізичної ознаки предмета предикатних злочинних дій.

Положення Закону України від 06.12.2019 № 361-IX та чинної редакції ст. 209 КК України в частині визначення основних категорій мають невідповідності та потребують застосування уніфікованого підходу для усунення протиріч.

Категорії майно та доходи, одержані злочинним шляхом, $є$ взаємодоповнюючими та в сукупності складають зміст особливостей фізичної ознаки предмета предикатних злочинних дій. Разом з тим, у розумінні законодавчого підходу для узагальнення сучасних предметів матеріального світу, отриманих злочинним шляхом, оптимальним 6 застосування в нормах кримінального законодавства терміна саме доходи, одержані злочинним шляхом. 


\section{Мітература}

1. Кримінальне право України: Заг. частина: Підручник / За заг. ред. М.І. Бажанова, В.В. Сташиса, В.Я. Тація. - Харків: Право, 1998 - С. 73.

2. Чаричанський О.О. Підстави кримінальної відповідальності за легалізацію (відмивання) доходів, одержаних злочинним шляхом, за Кримінальним кодексом України : дис. канд. юр. наук : 12.00.08. Харків, 2004. - 205 с.

3. Тацій В.Я. Об'єкт та предмет злочину за радянським кримінальним правом. Харків: Вища школа, 1988. - 197 с.

4. Про запобігання та протидію легалізації (відмиванню) доходів, одержаних злочинним шляхом, фінансуванню тероризму та фінансуванню розповсюдженню зброї масового знищення : Закон України від 06.12.2019 № 361-IX - [Електронний ресурс]. - Режим доступу: https://zakon.rada. gov.ua/laws/show/361-20\#n880.

5. Про Сорок рекомендацій Групи 3 розробки фінансових заходів боротьби 3 відмиванням грошей (FATF) : Постанова Кабінету Міністрів України і Національного Банку України від 28.08.2011 № 1124. - [Електронний ресурс]. - Режим доступу: https://zakon.rada.gov.ua/laws/show/11242001-\%D0\%BF\#Text.

6. Про внесення змін до Кримінального та Кримінально-процесуального кодексів України : Закон України від 16.01.2003 № 430 -IV - [Електронний ресурс]. - Pежим доступу: https://zakon.rada.gov.ua/laws/ show/430-15\#Text.

7. Про запобігання та протидію легалізації (відмиванню) доходів, одержаних злочинним шляхом, фінансуванню тероризму та фінансуванню розповсюдженню зброї масового знищення : Закон України від 06.12.2019 № 361-IX - [Електронний ресурс]. - Режим доступу: https://zakon.rada. gov.ua/laws/show/361-20\#n880.

8. Кримінальне право України: Загальна частина : Підручник / За заг. ред. М.І. Бажанова, В.В. Сташиса, В.Я. Тація. Харків: 1998. - С. 78.

9. Про запобігання та протидію легалізації (відмиванню) доходів, одержаних зло- чинним шляхом, фінансуванню тероризму та фінансуванню розповсюдженню зброї масового знищення : Закон України від 28.11.2002 № 249-IV - [Електронний ресурс]. - Режим доступу: https://zakon.rada. gov.ua/laws/show/249-15\#Text.

10. Про банки та банківську діяльність : Закон України від 07.12.2000 № 2121-III - [Електронний ресурс]. - Режим доступу: https://zakon.rada.gov.ua/laws/show/212114\#Text.

11. Про платіжні системи та переказ коштів в Україні : Закон України від 05.04.2001 № 2346-III - [Електронний pecypc]. - Режим доступу: https://zakon.rada. gov.ua/laws/show/2346-14\#Text.

12. Про затвердження Інструкції про безготівкові розрахунки в Україні в національній валюті : Постанова Національного банку України від 21.01.2004 р. № 22 - [Електронний ресурс]. - Режим доступу: https://zakon.rada.gov.ua/laws/show/z037704\#Text.

13. Про затвердження Національного положення (стандарту) бухгалтерського обліку 1 «Загальні вимоги до фінансової звітності» : Наказ Міністерства Фінансів України від 07.02.2013 р. № 73 - [Електронний ресурс]. - Режим доступу: https://zakon.rada.gov.ua/laws/show/z033613\#Text.

14. Губарик О.М. Інтерпретація поняття «Грошові кошти та їх еквіваленти» за національними та міжнародними стандартами бухгалтерського обліку /О.М. Губарик, I.C. Приходько // - [Електронний ресурс]. - Режим доступу: http:/global-national.in.ua/ archive/20-2017/192.pdf.

15. Економічний словник / упоряд. Й.С. Завадський, Т.В. Осовська, О.О. Юшкевич. Київ : Кондор, 2006. 355 с.

16. Фінансово-економічний словник: словник-довідник / кол. авт. : Юнін О. С., Круглова О. О., Савєльєва М. О. та ін. Дніпро : Видавець Біла К. О., 2018. - 164 с.

17. Цивільний кодекс України : Кодекс України від від 16.01.2003 № 435-IV - [Електронний ресурс]. - Режим доступу: https:// zakon.rada.gov.ua/laws/show/435-15\#n 1099.

18. Про валюту і валютні операції : Закон України від 21.06.2018 № 2473-VIII - 
[Електронний ресурс]. - Режим доступу: https://zakon.rada.gov.ua/laws/show/247319\#Text.

19. Гузь Є. В. "Майно” як цивілістична категорія [Текст] / Є. В. Гузь // Науковий вісник Ужгородського національного університету : Серія: Право / гол. ред. Ю.М. Бисага. - Ужгород : Гельветика, 2013. - Вип. 21. Т1 Ч.2. - С. 182-185.

20. Про судову практики у справах про злочини проти власності : Постанова Пленуму Верховного Суду України від 06.11.2009 № 10 - [Електронний ресурс]. - Режим доступу: https://zakon.rada.gov.ua/ laws/show/v0010700-09\#Text.

\section{INCOME WHICH MAY BE THE SUBJECT OF A PREDICATE CRIMINAL OFFENSE}

The shortcomings of the criminal legislation on bringing to justice for committing socially dangerous acts related to the legalization (laundering) of property obtained by criminal means sufficiently complicate the possibilities of criminal law counteraction to such negative social phenomena. The need to ensure the correct qualification of criminal acts, as a result of which property is acquired, requires the formation of a conceptual approach to those enshrined in Art. 209 of the Criminal Code of Ukraine of categories which generalize the existing objects of the material world, received in such illegal way.

The purpose of the article is to develop a scientific basis for determining the components of the category «proceeds of crime» and provide specific proposals for improving legislation in this area.

The scientific novelty of the study is related to the further development of scientific thought on the definitions of "property», «income», as well as «criminally obtained assets». The meaning and ratio of the categories «funds» and «currency values» are clarified.

Based on a critical analysis of domestic criminal law, as well as the Law of Ukraine of 06.12.2019 № 361-IX «On prevention and counteraction to legalization (laundering) of proceeds from crime, terrorist financing and financing the proliferation of weapons of mass destruction», developed regulatory legal provisions on objects of the material world, which belong to the category of property and income received as a result of committing a criminal offense. On the basis of theoretical generalization the author's vision to improvement of norms of the legislation in this sphere is formed.

Conclusions. Summing up, we note that with the entry into force of the Law of Ukraine of 06.12.2019 № 361-IX «On prevention and counteraction to legalization (laundering) of proceeds from crime, terrorist financing and financing of proliferation of weapons of mass destruction», as well as a new version of Art. 209 of the Criminal Code of Ukraine, the approaches to the formulation of the physical feature of the subject of predicate criminal acts have changed. However, the categories enshrined in the norms of these legislative acts have inconsistencies and need to be harmonized.

The category of proceeds of crime is a generic category and combines items of the material world that are valued and acquired as a result of committing a socially dangerous act for which criminal liability is provided.

Author's approach to improving the provisions of the Law of Ukraine dated 06.12.2019 № 361-IX, as well as Part 1 of Art. 209 of the Criminal Code of Ukraine provides that from the point of view of criminal law, detailing in the specified norm of the criminal legislation of types or groups of property has relative character and has no value for qualification, however for the purpose of avoidance of differences at interpretation of norms prevention and counteraction to legalization (laundering) of proceeds from crime, the same approach should be provided to the definitions of the main categories that cover the objects of the material world, which may become the subject of a predicate criminal offense.

Key words: predicate crime, legalization (laundering) of property, income, property, assets. 